\title{
Hubungan antara Jenis Kelamin dan Kejadian Kematian Mendadak di RSUP Prof. Dr. R. D Kandou Manado
}

\author{
${ }^{1}$ Gerrit J. Pangemanan \\ ${ }^{2}$ Djemi Tomuka \\ ${ }^{2}$ Nola T. S Mallo
}

\author{
${ }^{1}$ Program Studi Pendidikan Dokter Fakultas Kedokteran Universitas Sam Ratulangi Manado \\ ${ }^{2}$ Bagian Ilmu Kedokteran Forensik dan Medikolegal Fakultas Kedokteran \\ Universitas Sam Ratulangi Manado \\ Email: gerrit.j.pangemanan@gmail.com
}

\begin{abstract}
Sudden death could occur in anyone regardless of gender either male or female. This study was aimed to determine the relationship between gender and the incidence of sudden death at Prof. Dr. R. D. Kandou Hospital Manado. This was a descriptive analytical study with across sectional design using total sampling method. The results showed 345 cases of sudden deaths consisted of 209 males and 136 females. The age ranges were $0-1$ years $(7$ cases), 1-18 years ( 7 cases), 18-40 years (38 cases), 40-60 years (138 cases), and >60 years (155 cases). Coronary heart disease was the leading cause of sudden deaths (40 cases). Data analyzed by using Chi-square test showed a $P$ value of 0.838 . Conclusion: There was no relationship between gender and the incidence of sudden death. Sudden deaths were most common among males, age $>60$ years, with coronary heart disease as the most common cause of sudden death.
\end{abstract}

Keywords: gender, sudden death

\begin{abstract}
Abstrak: Kematian mendadak dapat terjadi pada siapa saja, tidak memandang jenis kelamin baik laki-laki maupun perempuan. Penelitian ini bertujuan untuk mengetahui hubungan antara jenis kelamin dan kejadian kematian mendadak di RSUP Prof. Dr. R. D Kandou Manado. Jenis penelitian ialah deskriptif analitik dengan desain potong lintang menggunakan metode total sampling. Hasil penelitian mendapatkan 345 kasus kematian mendadak terdiri dari 209 laki-laki dan 136 perempuan. Rentang usia 0-1 tahun berjumlah 7 kasus, usia 1-18 tahun berjumlah 7 kasus, usia 18-40 tahun berjumlah 38 kasus, usia 40-60 tahun berjumlah 138 kasus, dan usia >60 tahun berjumlah 155 kasus. Penyakit jantung koroner merupakan penyebab kematian mendadak terbanyak dengan jumlah 40 kasus. Analisis data menggunakan uji chi-kuadrat mendapatkan $P=0,838$. Simpulan: Tidak terdapat hubungan antara jenis kelamin dengan kejadian kematian mendadak. Sebagian besar kematian mendadak ditemukan pada laki-laki, kelompok usia $>60$ tahun, dengan penyebab penyakit jantung koroner.
\end{abstract}

Kata kunci: jenis kelamin, kematian mendadak

Kematian adalah suatu hal yang tidak bisa dihindari dan dapat terjadi pada semua orang tanpa memandang waktu dan tempat Kematian tidak dapat diubah dan merupakan penghentian dari suatu proses kehidupan alamiah. ${ }^{1}$

World Health Organization mendefinisikan kematian mendadak yaitu seseorang yang mati pada 24 jam sejak gejala- gejala timbul, namun pada kasus forensik sendiri sebagian besar kematian itu terjadi hanya dalam hitungan menit atau bahkan detik sejak gejala pertama timbul. ${ }^{2}$

Penyebab tersering kejadian kematian mendadak yaitu akibat penyakit kardiovaskuler. Setiap tahun diperkirakan 300.000-400.000 kematian mendadak terjadi di Amerika Serikat dengan mayori- 
tas disebabkan oleh penyakit kardiovaskuler. ${ }^{3,4}$ Di Eropa insiden kasus kejadian kematian mendadak dilaporkan berkisar antara 50 sampai 100 per 100.000 penduduk setiap tahun. ${ }^{5}$ Kejadian kematian mendadak di Indonesia sendiri yang disebabkan oleh penyakit kardiovaskuler diperkirakan terjadi pada 500.000 penduduk setiap tahun. ${ }^{6}$

Penelitian yang dilakukan di Arab Saudi mendapatkan persentase kasus kejadian kematian mendadak yaitu $17,5 \%$ dari total jumlah kematian yang ada, dimana persentase kematian mendadak dengan jenis kelamin laki-laki sebesar $56 \%$ dan perempuan $42,2 \%{ }^{7}$

Di Provinsi Sulawesi Utara sendiri khususnya di Manado pada penelitian yang dilakukan oleh Bhaskara et al. ${ }^{8}$ di Bagian Kedokteran Forensik RSUP Prof Dr. RD Kandou Manado pada tahun 2012 mendapatkan persentase kematian mendadak untuk laki-laki sebesar $87,5 \%$ dan perempuan $12,5 \%{ }^{8}$

Berdasarkan laporan penelitian di atas didapatkan gambaran hasil bahwa kematian mendadak lebih sering dialami oleh jenis kelamin laki-laki daripada perempuan. Namun, hingga saat ini hubungan antara jenis kelamin dan kematian mendadak belum pasti diketahui.

\section{METODE PENELITIAN}

Penelitian ini bertujuan untuk mengetahui hubungan antara jenis kelamin dengan kejadian kematian mendadak berdasarkan data rekam medik di Instalasi Gawat Darurat RSUP Prof. Dr. R. D. Kandou Manado periode Juli 2016-Juni 2017. Jenis penelitian ini ialah deskriptif analitik dengan desain potong lintang. Pengambilan sampel menggunakan metode total sampling. Analisis data menggunakan uji chi-kuadrat dengan jenis kelamin sebagai variabel independen dan kematian mendadak sebagai variabel dependen.

\section{HASIL PENELITIAN}

Dari penelitian yang dilakukan di RSUP Prof. Dr. R. D. Kandou Manado, khususnya di Instalasi Gawat Darurat dan Bagian Rekam Medik didapatkan data sekunder yaitu catatan rekam medik tentang kematian mendadak yang masuk di Instalasi Gawat Darurat RSUP Prof. Dr. R. D. Kandou Manado selama periode 1 tahun yaitu Juli 2016-Juni 2017. Berdasarkan data tersebut didapatkan jumlah kasus kematian mendadak sebanyak 345 kasus.

Analisis univariat bertujuan untuk menjelaskan atau memberikan gambaran mengenai karakteristik dari masing-masing variabel yang telah diteliti. Data univariat meliputi usia, jenis kelamin dan penyebab kematian sebagai variabel independen. Analisis setiap variabel independen dijabarkan terhadap kejadian kematian mendadak berdasarkan data sekunder yangf diperoleh.

Berdasarkan Tabel 1, kasus kejadian kematian mendadak yang masuk di RSUP Prof. Dr. R. D. Kandou Manado periode Juli 2016-Juni 2017 paling banyak dialami oleh lansia pada usia $>60$ tahun sebanyak 155 kasus $(44,9 \%)$. Bayi dan anak dengan rentang usia 0-1 tahun dan 1-18 tahun memiliki jumlah kasus kejadian kematian mendadak paling sedikit dengan jumlah sebanyak 7 kasus (2\%) pada masingmasing kelompok usia.

Tabel 1. Jumlah kematian mendadak berdasarkan kelompok usia

\begin{tabular}{ccc}
\hline $\begin{array}{c}\text { Kasus kematian } \\
\text { mendadak }\end{array}$ & $\begin{array}{c}\text { Kelompok } \\
\text { usia (tahun) }\end{array}$ & Jumlah \\
\hline Bayi & $0-1$ tahun & 7 \\
Anak & $1-18$ tahun & 7 \\
Dewasa muda & $18-40$ tahun & 38 \\
Dewasa & $40-60$ tahun & 138 \\
Lanjut usia & $>60$ tahun & 155 \\
Total & & 345 \\
\hline
\end{tabular}

Pada penelitian ini didapatkan jenis kelamin laki-laki lebih banyak mengalami kematian mendadak dibandingkan dengan perempuan. Laki-laki memiliki jumlah sebanyak 209 kasus (61\%) sedangkan perempuan 136 kasus (39\%) dari total keseluruhan kasus yaitu 345 kasus (Gambar 1). 


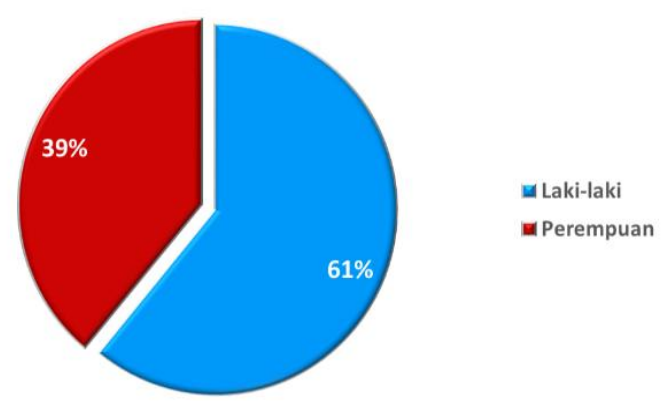

Gambar 1. Kematian mendadak berdasarkan jenis kelamin
Berdasarkan Gambar 2 didapatkan hasil bahwa penyakit jantung koroner merupakan penyebab terbanyak kematian mendadak dengan jumlah 40 kasus $(11,6 \%)$, diikuti oleh pneumonia dan syok septik berjumlah 38 kasus (11\%) dan 32 kasus $(9,3 \%)$. Kasus kematian mendadak yang diakibatkan oleh melena, asma bronkial, infark otak dan infeksi saluran kemih hanya didapatkan masing-masing sebanyak 2 kasus $(0,7 \%)$ untuk setiap kasus.

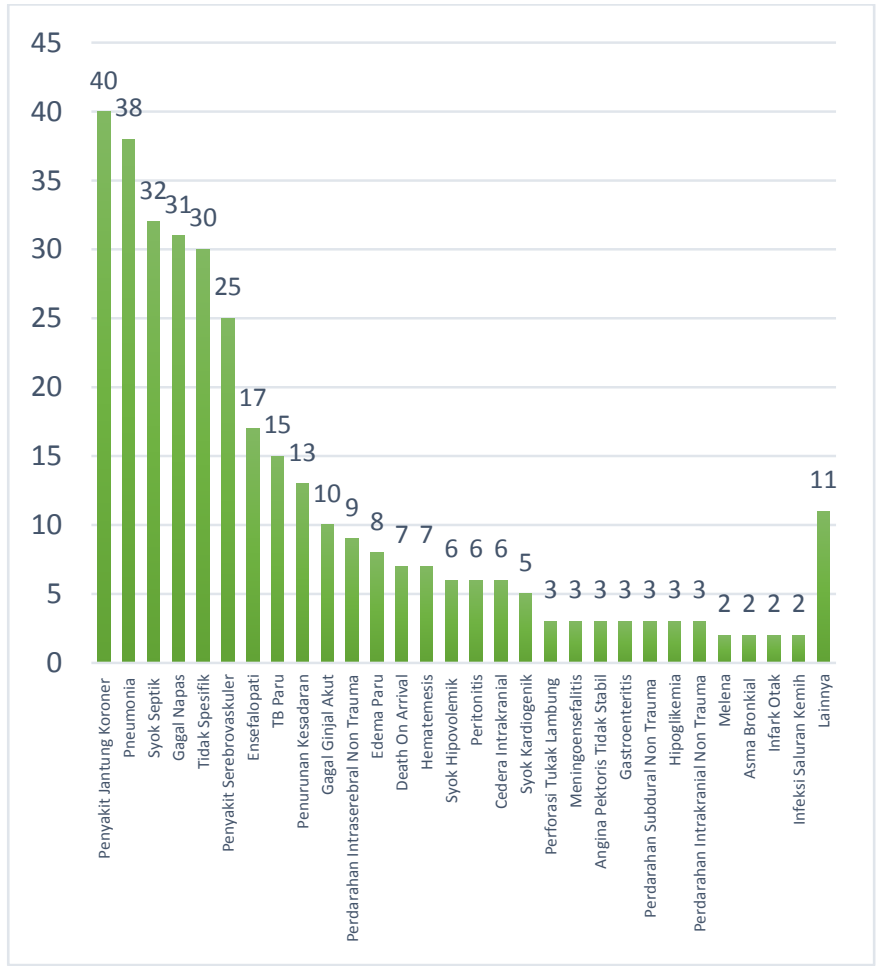

Gambar 2. Penyebab kematian mendadak

Tabel 2 menunjukkan hubungan antara jenis kelamin dengan kejadian kematian mendadak. Jenis kelamin laki-laki lebih banyak menderita kematian mendadak $(26,7 \%)$ dan kematian tidak mendadak (36,3\%) dibandingkan perempuan dengan persentase kematian mendadak sebesar $(16,1 \%)$ dan kematian tidak mendadak (22,9\%). Jumlah kasus kejadian kematian tidak mendadak di RSUP Prof. Dr. R. D Kandou Manado periode Juli 2016-Juni 2017 sebesar 501 kasus yang terdiri dari laki-laki sebanyak 307 kasus dan perem- puan sebanyak 194 kasus dengan kasus kematian tidak mendadak yang lebih besar $(59,2 \%)$ dibandingkan dengan kematian mendadak $(40,8 \%)$.

Hasil uji analisis bivariat menggunakan uji chi-square melalui program pengolahan data SPSS dengan derajat kepercayaan $95 \%(\alpha=0,05)$ memperlihatkan nilai $P=0,838$ yang menunjukkan tidak terdapat hubungan bermakna antara jenis kelamin dengan kejadian kematian mendadak di RSUP Prof. Dr. R. D Kandou Manado periode Juli 2016- Juni 2017. 
Pangemanan, Tomuka, Mallo: Hubungan antara jenis kelamin dan kejadian ...

Tabel 2. Hubungan antara jenis kelamin dengan kejadian kematian mendadak

\begin{tabular}{ccccccccc}
\hline & \multicolumn{3}{c}{ Kematian mendadak } & \multicolumn{2}{c}{ Jumlah } & \multirow{2}{*}{$P$-value } \\
\cline { 2 - 6 } Jenis kelamin & \multicolumn{3}{c}{ Ya } & \multicolumn{3}{c}{ Tidak } & & \\
\cline { 2 - 7 } & $\mathrm{n}$ & $\%$ & $\mathrm{n}$ & $\%$ & $\mathrm{n}$ & $\%$ & \\
\hline Laki-Laki & 209 & 24,7 & 307 & 36,3 & 516 & 61,0 & \\
Perempuan & 136 & 16,1 & 194 & 22,9 & 330 & 39,0 & 0.838 \\
Jumlah & 345 & 40,8 & 501 & 59,2 & 846 & 100 & \\
\hline
\end{tabular}

\section{BAHASAN}

Penelitian ini menunjukkan jumlah kasus kejadian kematian mendadak di RSUP Prof. Dr. R. D Kandou Manado periode Juli 2016-Juni 2017 berdasarkan usia bahwa kelompok lansia dan dewasa yaitu dengan rentang usia $>60$ tahun dan 40-60 tahun merupakan rentang usia tertinggi dan kedua tertinggi dalam kasus kejadian kematian mendadak (Tabel 1). Hal ini sejalan dengan penelitian yang dilakukan di Arab Saudi yang juga menunjukkan bahwa kematian mendadak tertinggi dialami oleh lansia ( $>60$ tahun) sebesar $31,4 \%$ diikuti dengan dewasa (4060 tahun) sebesar 21\%. ${ }^{7}$ Juga selaras dengan penelitian yang dilakukan di Surakarta, lansia mengalami kematian mendadak yang lebih sering dibandingkan kelompok usia lain dengan persentase $45 \%$. ${ }^{9}$ Kematian mendadak lebih sering terjadi pada usia lanjut karena penyakit yang sering menyebabkan kematian mendadak sebagian besar ialah penyakit yang risikonya bertambah seiring dengan pertambahan usia seperti penyakit jantung koroner.

Hasil penelitian ini agak berbeda dengan penelitian Supit et al. $^{10}$ yang dilakukan di Manado pada periode 20152016 dimana kelompok usia 40-60 tahun merupakan yang tertinggi dengan jumlah 221 kasus dibandingkan dengan kelompok usia >60 tahun dengan jumlah 204 kasus dari jumlah 602 kasus secara keseluruhan.

Gambar 1 menunjukkan bahwa jenis kelamin laki-laki lebih banyak mengalami kematian mendadak dibandingkan perempuan dengan perbandingan sebesar 3:2. Penelitian ini selaras dengan penelitian yang dilakukan di Nigeria dimana laki-laki lebih sering mengalami kematian mendadak dari pada perempuan dengan perbandingan rasio sebesar 2,1:1. ${ }^{11}$ Kematian mendadak lebih sering terjadi pada laki-laki dibandingkan perempuan juga dilaporkan di Korea Selatan dengan laki-laki sebesar $71,1 \%$ dan perempuan sebesar $28,9 \% .^{12}$

Penelitian yang dilakukan di Surakarta, Indonesia pun menunjukkan hal yang sejalan dimana laki-laki (74\%) lebih sering mengalami kematian mendadak dibandingkan perempuan $(26 \%) .{ }^{9}$ Hal ini dapat terjadi karena laki-laki memang lebih rentan atau memiliki risiko yang lebih tinggi untuk terkena penyakit yang sering menyebabkan kematian mendadak seperti penyakit jantung dan lainnya.

Penyebab kematian mendadak di RSUP Prof. Dr. R. D Kandou Manado periode Juli 2016-Juni 2017 berdasarkan Gambar 2 menunjukkan bahwa penyebab kematian mendadak paling sering ialah penyakit jantung koroner yang merupakan penyakit kardiovaskuler. Hal ini sejalan dengan laporan kematian mendadak di Amerika Serikat bahwa setiap tahunnya diperkirakan terdapat 300.000-400.000 kematian akibat penyakit kardiovaskuler. ${ }^{3,4}$

Menurut WHO pada tahun 2015 diperkirakan 17,7 juta orang meninggal akibat penyakit kardiovaskuler yang mencakup $31 \%$ kematian di seluruh dunia. Sehingga menempatkan penyakit kardiovaskuler sebagai pembunuh nomor 1 di dunia. ${ }^{13}$

Tabel 2 menunjukkan hasil analisis hubungan antara jenis kelamin dengan kejadian kematian mendadak di RSUP Prof. Dr. R. D Kandou Manado periode Juli 
2016-Juni 2017 yang menunjukkan tidak terdapat hubungan bermakna. Jenis kelamin dengan kejadian kematian mendadak tidak berhubungan; hal ini dapat disebabkan oleh jumlah kasus kematian tidak mendadak yang lebih banyak dibandingkan dengan kematian mendadak sehingga jenis kelamin tidak memiliki hubungan bermakna dengan kejadian kematian mendadak.

Berdasarkan hasil tersebut juga diketahui bahwa jenis kelamin laki-laki memiliki jumlah kasus yang lebih banyak baik pada kematian mendadak maupun kematian tidak mendadak dibandingkan perempuan. Laki-laki memiliki risiko kejadian kematian mendadak empat kali lebih sering dibandingkan perempuan dengan penyakit jantung dan pembuluh darah merupakan urutan pertama dalam penyebab kematian mendadak. ${ }^{14,15}$

\section{SIMPULAN}

Berdasarkan hasil penelitian dapat disimpulkan bahwa tidak terdapat hubungan bermakna antara jenis kelamin dengan kejadian kematian mendadak. Kelompok usia yang paling banyak mengalami kematian mendadak ialah lansia dengan rentang usia >60 tahun. Jenis kelamin lakilaki lebih banyak mengalami kematian baik mendadak maupuon tidak mendadak daripada perempuan dengan penyakit jantung koroner sebagai penyebab tersering.

\section{DAFTAR PUSTAKA}

1. Australian Institute of Health and Welfare. Multiple causes of death: an analysis of all natural and selected chronic disease causes of death 19972007 (online version).

2. James JP, Jones R, Karch SB, Manlove J. Simpson's Forensic Medicine (13th ed). London: Hodder\&Stoughton Ltd, 2011.

3. Engelstein ED, Zipes DP. Sudden cardiac death. In: Alexander RW, Schlant RC, Fuster V, editors. The Heart, Arteries and Veins. New York: McGraw-Hill, 1998; p. 1081-112.

4. Myerburg RJ, Castellanos A. Cardiac arrest and sudden death. In: Braunwald E, ed. Heart Disease: A
Textbook of Cardiovascular Medicine. Philadelphia: Saunders, 1997; p. 742-79.

5. Prescrire. Domperidone an indication of how many sudden deaths. Prescrire Analysis; 2014.

6. Okvitasari Y, Hamzah, Muhsinin. Analisis faktor-faktor yang berhubungan dengan kejadian penyakit jantung koroner di Poliklinik Jantung RSUD Ulin Banjarmasin. Caring. 2016;2(2).

7. Nofal HK, Abdulmohsen MF, Khamis AH. Incidence and causes of sudden death in a university hospital in eastern Saudi Arabia. EMHJ. 2011;17:665-70.

8. Bhaskara DSM, Mallo J, Tomuka D. Hasil autopsi sebab kematian mendadak tak terduga di Bagian Forensik BLU RSUP. Prof. Dr. R. D. Kandou Manado tahun 2010-2012 [Skripsi]. Manado: Universitas Sam Ratulangi; 2012.

9. Rahmawati MLA. Hubungan antara usia dengan prevalensi dugaan mati mendadak [Skripsi]. Surakarta: Fakultas Kedokteran Universitas Sebelas Maret; 2010.

10. Supit GC, Tomuka D, Siwu F. Hubungan antara usia dengan kejadian kematian mendadak di RSUP Prof. Dr. R. D. Kandou Manado periode Mei 2015April 2016 [Skripsi]. Manado. Universitas Sam Ratulangi; 2016.

11. Pelemo OY, Sabageh D, Komolafe AO, Sabageh AO, Odensami WO. An autopsy review of sudden unexpected natural deaths in a suburban Nigerian population. Population Health Metrics.2014;12:26.

12. Lee WT, Cho WY, Ki CD, Kim JK, Kang SM. The Statistical Analysis on Legal Autopsy in 2006 (The Headquarters of National Institute of Scientific Investigation). Korean $\mathbf{J}$ Leg Med 2007; 31:139-46.

13. WHO. Cardiovascular diseases. Mei 2017. [diakses: 8/11/17]. Tersedia di: http://www.who.int/mediacentre/facts heets/fs317/en/

14. Hakim FA. Aspek Medikolegal Kematian Mendadak Akibat Penyakit (Natural Sudden Death). Fakultas Kedokteran UNJANI: Research and Learning Unit; 2010. 
Pangemanan, Tomuka, Mallo: Hubungan antara jenis kelamin dan kejadian ...

15. Fadhillah R. Profil Kejadian Kematian Mendadak di Departemen Kedokteran Forensik FK USU/ SMF Kedokteran
Forensik RSUD Dr. Pirngadi Medan Periode 2009-2011 [Skripsi]. Medan: Fakultas Kedokteran USU; 2012 